\title{
A tale of shells and claws: The signal crayfish as a threat to the pearl mussel Margaritifera margaritifera in Europe
}

\author{
Ronaldo Sousa a,*, Joana Garrido Nogueira a , André Ferreira a , Francisco Carvalho ${ }^{\text {a,b }}$, Manuel Lopes-Lima c \\ Simone Varandas ${ }^{\mathrm{d}}$, Amílcar Teixeira ${ }^{\mathrm{e}}$ \\ a CBMA - Centre of Molecular and Environmental Biology, Department of Biology, University of Minho, Campus Gualtar, 4710-057 Braga, Portugal \\ ${ }^{\mathrm{b}}$ IB-S - Institute of Science and Innovation for Bio-Sustainability, University of Minho, Campus Gualtar, 4710-057 Braga, Portugal \\ c CIBIO/InBIO - Research Center in Biodiversity and Genetic Resources, University of Porto, Campus Agrário de Vairão, Vairão, Portugal \\ d CITAB-UTAD - Centre for Research and Technology of Agro-Environment and Biological Sciences, University of Trás-os-Montes and Alto Douro, Forestry Department, Vila Real, Portugal \\ e Centro de Investigação de Montanha (CIMO), Instituto Politécnico de Bragança, Campus de Santa Apolónia, 5300-253 Bragança, Portugal
}

\section{H I G H L I G H T S}

- We assessed the predation of crayfishes on freshwater pearl mussels.

- In the laboratory, predation of freshwater pearl mussels was size dependent.

- In the field, predation of freshwater pearl mussels was density dependent.

- Invasive crayfishes may impair the conservation of freshwater pearl mussels.
GR A P H ICA L A B S T R A C T

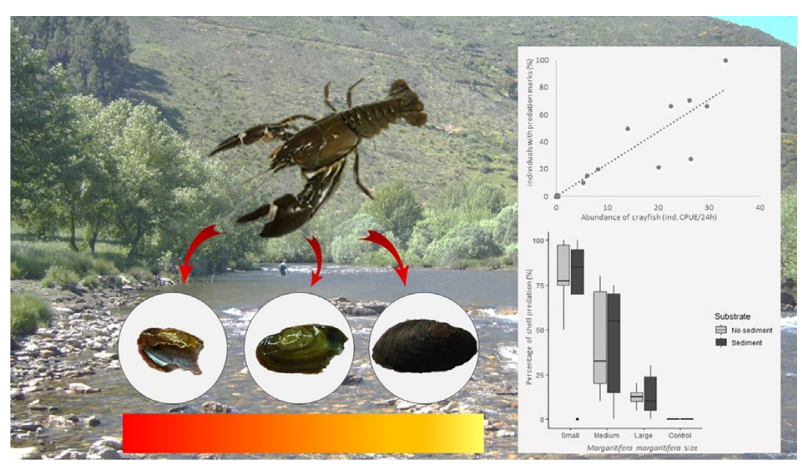

\section{A B S T R A C T}

The freshwater pearl mussel Margaritifera margaritifera is a highly threatened species in Europe. Several mechanisms may be responsible for the decline in distribution and abundance of European pearl mussel populations, but almost no quantitative data exists about the possible negative impacts of invasive alien species (IAS). In this study, we clearly demonstrate that the invasive signal crayfish Pacifastacus leniusculus predates pearl mussels, using a laboratorial experiment followed by in situ validation in four rivers in the North of Portugal (Mente, Rabaçal, Tuela and Baceiro Rivers; Douro Basin). In the laboratory, the crayfish had a clear preference for small-sized pearl mussels but no differences in predation were found in mesocosms with and without sediment. In addition, we clearly demonstrated that the signal crayfish predates pearl mussels in natural conditions and detected a significant density dependent effect (i.e., sites with more crayfish presented higher number of pearl mussel shells with marks of predation). Given the recent introduction of the signal crayfish and the potential negative impacts on pearl mussel populations we also investigated its autoecology (distribution, abundance, size structure and sex-ratio) in the four studied rivers. Significant differences in average abundance and size of the crayfish were detected between sites and the sex-ratio was highly skewed to females. In view of the widespread distribution of signal crayfish (and other invasive crayfish species) in Europe, future management actions devoted to the conservation

\footnotetext{
* Corresponding author.

E-mail address: rg.eco.sousa@gmail.com (R. Sousa).
} 
of pearl mussels should take in consideration the possible negative effects of these predators, especially on juveniles.

\section{Introduction}

The introduction of predators may affect the structure and function of many terrestrial and aquatic ecosystems (Doherty et al., 2016). Several dramatic examples include the introduction of rats (ship rat Rattus rattus, brown rat Rattus norvegicus, Pacific rat Rattus exulans) in islands and its impacts on birds and lower trophic levels (Fukami et al., 2006; Kurle et al., 2008); brown tree snake Boiga irregularis in Guam and its impacts on endemic birds (Rogers et al., 2017); Burmese python Python bivittatus in the Everglades (Florida, USA) and its impacts on mammals (Dorcas et al., 2012), among many others. These are well known studies that showed significant direct effects on prey, but others highlight that some of these introduced predators can be also responsible for important changes in community structure and ecosystem functions. For example, the presence of Arctic fox (Vulpes lagopus) in the Aleutian Islands significantly reduced bird populations with consequent cascading effects on nutrient cycling and plant and macroinvertebrate communities (Croll et al., 2005; Maron et al., 2006). In freshwater ecosystems, some predators are also well recognized as having negative impacts on their prey, being the introduction of the Nile perch Lates niloticus in Lake Vitoria a good example of cascading effects to lower trophic levels and ecosystem functioning (Pringle, 2011). Some of these introductions in terrestrial and aquatic ecosystems have dramatic conservation consequences that can lead to the extinction of several endemic species (e.g., Blackburn et al., 2004). Therefore, the introduction of predators to a new ecosystem should be carefully monitored. This situation is even more urgent if some of their prey are rare and already suffering negative impacts from other disturbing pressures such as habitat loss and fragmentation, pollution, climate change and/or overexploitation.

The pearl mussel Margaritifera margaritifera is listed as globally Endangered and as Critically Endangered in Europe by the International Union for Conservation of Nature (IUCN). This conservation status is due to several human activities (see below) in addition to the species particular features (e.g., long life cycle with a prolonged juvenile stage, the need of a specific host to complete the juveniles metamorphose, narrow ranges of tolerance to several abiotic factors; see Geist (2010) for a review) that probably increase their vulnerability. In the last decades, habitat loss and fragmentation due to dams (or other infrastructures) construction, overexploitation for the pearl industry, climate change and pollution are usually described in the literature as the main factors responsible for extensive declines and failures in recruitment in European pearl mussel populations (Geist, 2010; Lopes-Lima et al., 2017; Santos et al., 2015; Varandas et al., 2013). In addition, some authors also report possible negative effects resulting from the introduction of several invasive alien species (IAS) on the abundance and distribution of freshwater mussel populations (Anastácio et al., 2019; Ferreira-Rodríguez et al., 2018; Meira et al., 2019; Sousa et al., 2014). This last point has been neglected and remains speculative, but the introduction of potential IAS competitors such as the Asian clam Corbicula fluminea, diseases, parasites or predators may negatively affect pearl mussels (Sousa et al., 2015). Muskrat Ondatra zibethicus predation on pearl mussels in their native range (New Brunswick, Canada) were reported by Zahner-Meike and Hanson (2001). Similar effects are possible on European pearl mussel populations living in sympatry with introduced muskrats (Lopes-Lima et al., 2017).

Although neglected, the possible introduction of non-native crayfish may also pose a threat to pearl mussel populations. In Europe, several non-native crayfish have been introduced, being Procambarus clarkii and Pacifactacus leniusculus the most widespread and problematic given the high ecological and economic impacts (Gherardi et al., 2011). In Portugal, there is a recent (first record of $P$. lenisuculus in the study area was in September 2013; Sousa et al., 2015) distribution overlap between $M$. margaritifera and P. leniusculus, and in a much lesser extent with P. clarkii, in Mente, Rabaçal and Tuela Rivers. These rivers are colonised by the healthiest and denser populations of $M$. margaritifera in Portugal (Sousa et al., 2015) and the possible predation by crayfish may represent an important, but unquantified, threat. Given this background, the aims of this study were to: i) assess predation of $P$. leniusculus on different size categories of M. margaritifera (with and without sediment) using a mesocosm experiment in controlled laboratorial conditions; ii) investigate, for the first time, the basic autoecology (distribution, abundance, size structure and sex-ratio) of the signal crayfish in Mente, Rabaçal, Tuela and Baceiro Rivers; iii) evaluate in situ predation of the signal crayfish on M. margaritifera; and iv) assess if there is any relationship between the abundance of crayfish and the level of pearl mussels predation. We predict that smaller $M$. margaritifera individuals in mesocosms without sediment will be more vulnerable to predation by the signal crayfish, following results obtained by Machida and Akiyama (2013) for Japanese pearl mussels. We also predict a clear relationship between the abundance of signal crayfish and the percentage of predated pearl mussels (i.e., a density dependent effect, with sites with more crayfish presenting higher signs of predation), following similar results already obtained by Meira et al. (2019) for other freshwater mussel species. Overall, data gathered in this study may be used to better understand the current distribution of the signal crayfish and the level of threat to pearl mussels.

\section{Material and methods}

\subsection{Study area}

Mente, Rabaçal, Tuela and Baceiro Rivers are tributaries of the Tua River (Douro basin) and have a total length of $57 \mathrm{~km}, 88 \mathrm{~km}, 102 \mathrm{~km}$, and $60 \mathrm{~km}$, respectively (Fig. 1). All rivers have their source in Spain but most of the areas occupied by their basins are located in Portugal. The four rivers are subjected to a similar climate, with precipitation and temperature having high seasonal and inter-annual variability and this situation may result in sudden changes in the river flows (Oliveira et al., 2012; Sousa et al., 2018). Maximum river flows are registered during winter/early spring, with a gradual decline throughout the year, reaching minimum values in the late summer/early autumn (Sousa et al., 2012 and 2018). Most of the study area is located in a protected area, the Montesinho Natural Park, and has a low human density and disturbance, with a dominant hardwood forest cover (mainly Quercus spp.) (Oliveira et al., 2012; Sousa et al., 2015 and 2018). All four rivers present a pool-riffle sequence and the dominant substrate is cobble, boulders, gravel and sand, with the exception of areas submitted to lentic conditions due to the presence of small reservoirs and weirs, where the dominant sediment is mud. The riparian vegetation in all rivers is dominated by the presence of alder (Alnus glutinosa), willow (Salix spp.), poplar (Populus nigra) and ash (Fraxinus angustifolia) trees.

The four rivers present a high biodiversity and conservation status (Oliveira et al., 2012; Sousa et al., 2015), representing important habitats for threatened species such as M. margaritifera (endangered), Macromia splendens (vulnerable), Galemys pyrenaicus (vulnerable) and Arvicola sapidus (vulnerable), among others (Oliveira et al., 2012; 


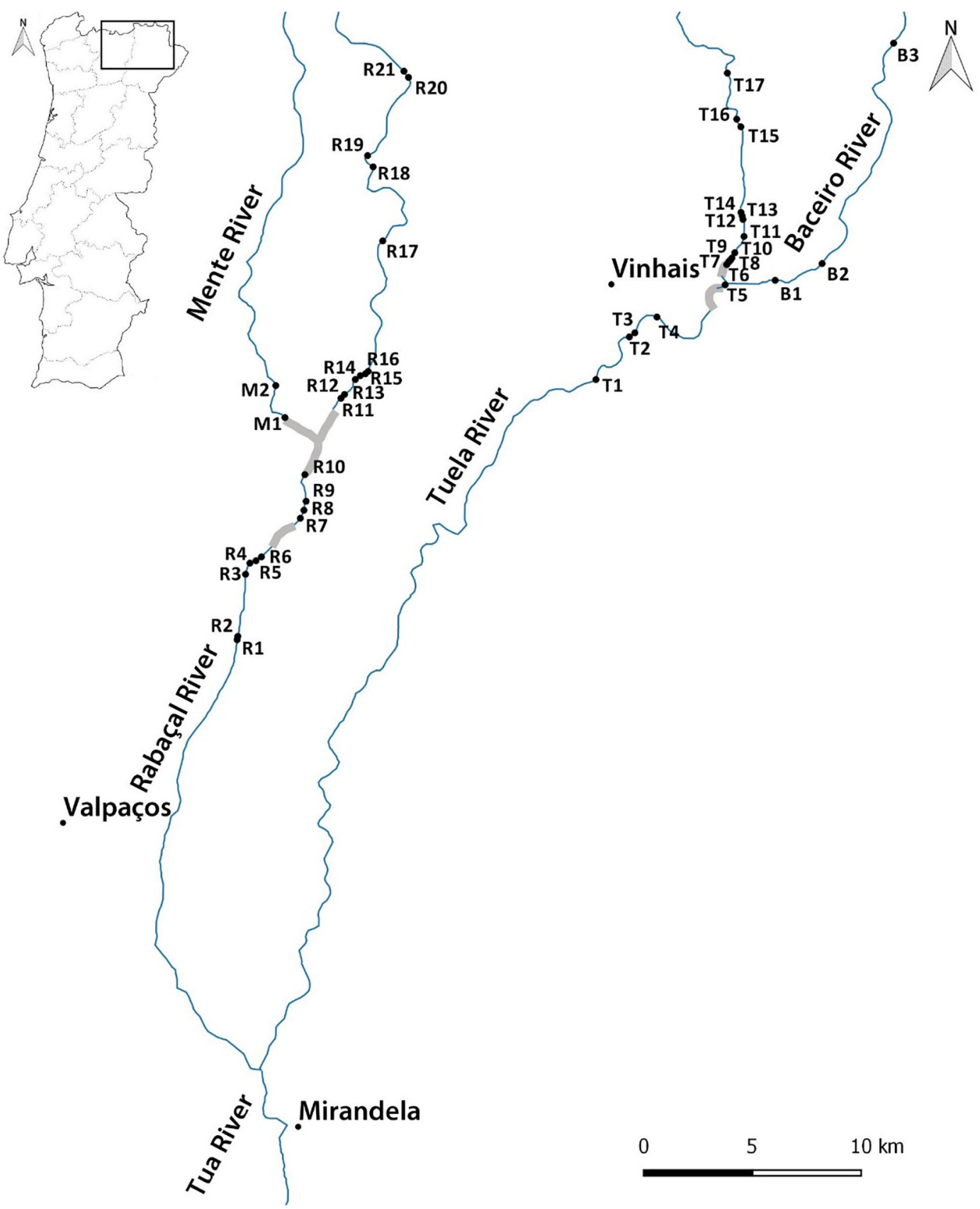

Fig. 1. Map showing the sampling site locations in Mente (M), Rabaçal (R), Tuela (T) and Baceiro (B) Rivers.

Sousa et al., 2015). Regarding the fish fauna, cyprinids such as Northern straight-mouth nase Pseudochondrostoma duriense (vulnerable), calandino Squalius alburnoides (vulnerable), Iberian barbel Luciobarbus bocagei and northern Iberian chub Squalius carolitertii, plus the Northern Iberian spined-loach Cobitis calderoni (endangered) from the Cobitidae family and brown trout Salmo trutta from the Salmonidae family are present. Recent studies, also highlight that three of these four rivers (i.e. Mente, Rabaçal and Tuela Rivers) present the most well preserved and still recruiting pearl mussel populations in Portugal (Sousa et al., 2015). Anyway, in the last years these populations have been declining in abundance due to impacts of droughts (Sousa et al., 2018) and habitat loss and fragmentation due to the presence of small dams (Sousa et al., 2015). In addition, the introduction of invasive species, including crayfish species such as P. clarkii and P. leniusculus, have been also described as an ecological and economic problem in Portuguese freshwater ecosystems (Anastácio et al., 2019). In the particular case of the signal crayfish, this species was first detected in Portugal in 1997 in the Maçãs River (tributary of the Sabor River, Douro basin) (Bernardo et al., 2011) and in two decades almost spread throughout the entire Sabor basin (Meira et al., 2019). In the Rabaçal and Tuela Rivers, which are nearby the Sabor basin, the first specimens were detected in 2013 (Sousa et al., 2015).

\subsection{Laboratorial experiment}

Permits to conduct the laboratorial experiment were obtained from the Portuguese Conservation Governmental Authority. All ethical requisites were accomplished, being the pearl mussels used in the laboratorial experiment released in the collection site after the experiment.

Margaritifera margaritifera and P. leniusculus individuals were collected in the Rabaçal River in site R21 (Fig. 1). Pearl mussels were 
collected after diving using snorkelling. Signal crayfishes were collected using small baited (using dead fish) traps placed in the river bottom for $24 \mathrm{~h}$. Both mussels and crayfishes were measured with a digital calliper to determine each individual size. For pearl mussels we used the maximum distance on the anterior-posterior axis (following Sousa et al., 2013a) and for crayfish we used the distance from the rostrum tip to telson rear edge (following Sousa et al., 2013b).

Animals (both pearl mussels and crayfishes) were always maintained under controlled temperature (water temperature of $17^{\circ} \mathrm{C}$, similar to the temperature measured in the river during late summer conditions) and photoperiod (12 h in the dark and $12 \mathrm{~h}$ with light) in the laboratory before (seven days to acclimatize to laboratorial conditions) and during the experiment. Bivalves were maintained in aquariums $(60 \times 30 \times 30 \mathrm{~cm})$ with $50 \mathrm{~L}$ of water under aeration and fed on microalgae. Each signal crayfish was maintained in separate aquariums $(60 \times 30 \times 30 \mathrm{~cm})$ in individual small cages with water under aeration and fed daily with freshwater fish food sticks. Before the experiment, crayfishes were starved for three days to promote their need for nutrition and reduce the effect of previous feeding condition following Meira et al. (2019). Only mature crayfish males with a similar size were used in the laboratorial experiment in order to minimize possible bias in the assessment of the predatory behaviour due to sex and size differences.

The predation experiment aimed to determine if: i) P. leniusculus recognized the pearl mussel as prey; ii) predation was dependent on the size of the pearl mussels and iii) predation was dependent on the presence/absence of sediment in the mesocosms. For this, we used a similar size of male crayfish specimens (mean \pm standard deviation of $102.1 \pm 7.1 \mathrm{~mm}$ ) but a wide range of sizes of pearl mussels (from a minimum of $22.0 \mathrm{~mm}$ to a maximum of $85.1 \mathrm{~mm}$ ).

Pearl mussels were introduced in the mesocosms (Aquaneering Systems ${ }^{\circledR}$ with aerated plastic containers and water quality control) $24 \mathrm{~h}$ before the beginning of the experiment. This procedure allowed pearl mussels to burrow in their natural position (when subjected to the treatment with sediment; see below) and adapt to the new conditions. Each mesocosm had $50 \mathrm{~cm}$ length, $25 \mathrm{~cm}$ width, and $22 \mathrm{~cm}$ height and were filled with $10 \mathrm{~L}$ of distilled water. We used a total of twelve treatments and each one was replicated 10 times $(N=120)$ and ran for $72 \mathrm{~h}$. Treatments consist in three size mussel categories: small (size range between 22.0 and $39.7 \mathrm{~mm}$ with an average $( \pm S D)$ of $31.9( \pm 4.5) \mathrm{mm})$; medium (size range between 42.2 and $60.0 \mathrm{~mm}$ with an average of $51.2( \pm 4.9) \mathrm{mm})$ and large (size range between 72.4 and $85.1 \mathrm{~mm}$ with an average of $77.4( \pm 3.6) \mathrm{mm})$. Each pearl mussel in each size category was subject to the presence of a single signal crayfish in mesocosms with or without (the perfect scenario for crayfish predation due to the absence of refuges) sediment. Mesocosms with sediment were covered by a $10 \mathrm{~cm}$ layer of sediment previously collected in R21 (Fig. 1). Sediment was mainly composed by cobble, gravel and sand, the preferred habitat of pearl mussels (Varandas et al., 2013; Sousa et al., 2015) and was previously washed and autoclaved as described by Carvalho et al. (2016). Controls consist in pearl mussels of the three different size categories in mesocosms with or without sediment and not subjected to signal crayfish presence. All mussels and crayfishes were used only once.

At the end of the experiment all pearl mussels were checked for mortality, and predation was assessed by inspection of the existence of characteristic marks on mussel shells (see for example Machida and Akiyama, 2013 and Meira et al., 2019). For mussel specimens presenting marks of predation, we visually estimated the percentage of shell with marks of predation along its perimeter, excluding the umbo.

\subsection{Field validation}

To validate the results of the laboratorial experiment and to characterize the basic autoecology of the signal crayfish, we performed a field survey in the Mente, Rabaçal, Tuela and Baceiro Rivers (North-eastern
Portugal). Although, no pearl mussels were ever found in the Baceiro River (Sousa et al., 2015; and present study) we include this river in the survey because signal crayfish was earlier detected there (Teixeira, personal observation).

To assess if crayfish predation occurs in the natural environment, a total of 43 sites were sampled during August 2017, 21 in Rabaçal, two in Mente, 17 in Tuela and three in Baceiro Rivers (Fig. 1). For each site, and for $M$. margaritifera characterization, a river stretch with a minimum of $50 \mathrm{~m}$ was surveyed covering distinct habitats such as riffles and pools, and areas near the banks and centre of the channel. These surveys were always performed by a minimum of two and a maximum of four experienced researchers and pearl mussels were found visually or by hand-searching (following the methodology described in Sousa et al., 2018). A total of four to nine replicates lasting 5 min were performed, being sites with lower abundances subjected to higher sampling effort. In each site, M. margaritifera specimens were collected, including empty shells, and their length was measured with a digital calliper. The percentage of pearl mussels that present the characteristic marks of predation left by crayfishes was also determined. All inspected pearl mussels were then returned to their habitat in their natural position.

The abundance and size structure of crayfish were assessed in the same 43 sites surveyed for pearl mussels, also during August 2017 (Fig. 1). Crayfishes were captured by placing eight to 10 funnel traps, four-five rectangular $(50 \times 30 \times 20 \mathrm{~cm} ; 0.5 \mathrm{~cm}$ mesh $)$ and four-five cylindrical (43 cm diameter; $22 \mathrm{~cm}$ height; $1.5 \mathrm{~cm}$ mesh), per site for $24 \mathrm{~h}$. Therefore, relative abundance of crayfish per site was expressed as the total number of individuals per catch per unit of effort (ind. CPUE/ $24 \mathrm{~h}$ ). The crayfishes collected were measured from the rostrum tip to telson rear edge and their sex was determined (following Sousa et al., 2013b).

\subsection{Data analysis}

In the laboratorial experiment, differences in mortality of M. margaritifera for each size category were assessed by the nonparametric Kruskall-Wallis test since data depart from normality even after several transformations. Differences in the percentage of shell predation were assessed by a two-way ANOVA. Factors were size categories (control small, control medium, control large, small, medium and large), substrate (sediment and no sediment) and their interaction. Dunnett's test was used to determine which size categories differed significantly from the control. In the field validation, differences in average abundance and size of crayfishes between sites, for the two basins (Rabaçal and Tuela) independently, were assessed by one-way ANOVA. Data were log-transformed when necessary in order to accomplish a normal distribution. All ANOVAs were preceded by the Shapiro-Wilk test to check if the residuals of the models had a Gaussian distribution, and the Bartlett test to check for homoscedasticity (Zar, 2009). To assess if possible differences in the sex ratios in both Rabaçal and Tuela basins differed from the 1:1 expectation a chi-square test was used. Differences in average size of crayfish between males and females, for the two basins (Rabaçal and Tuela), were assessed by a Mann Whitney test since data depart from normality even after several transformations. Finally, a Pearson correlation was performed to test the relationship between crayfish abundance and the percentage of pearl mussels that presented marks of predation.

All statistical tests were performed with $\mathrm{R}$ (version 3.4.4).

\section{Results}

\subsection{Laboratorial experiment}

Of the 120 pearl mussels (60 subjected to crayfish predation and 60 as control) used in the experiment, five died due to crayfish predation. All five pearl mussels belonged to the small size category: three 
specimens to the no sediment treatment ( $30 \%$ mortality) and two specimens to the sediment treatment (20\% mortality). Significant differences were found in mortality of pearl mussels in the comparison between size categories in the no sediment treatment $(\mathrm{H}=9.439 ; p=$ 0.024); however, no significant differences were found in the sediment treatment $(\mathrm{H}=6.158 ; p=0.104)$.

The percentage of the perimeter of the shell presenting marks of predationwas much higher in the small when compared to medium or large size categories $\left(F_{3,54}=71.78 ; p<0.001\right)$ (Fig. 2). Average percentage varied between 0 in the control of all size categories with and without sediment and $79.5 \%$ in the small size category with no sediment (Fig. 2). No significant differences were found in the comparison between treatments with and without sediment $\left(F_{1,18}=0.0 ; p>0.99\right)$ and no interaction was also found between size and sediment $\left(F_{3,54}=0.05 ; p=0.98\right)$.

\subsection{Field validation}

In total we collected 1606 crayfish ( $P$. clarkii and $P$. leniusculus), being 566 found in the Rabaçal basin (565 in Rabaçal and 1 in Mente) and 1040 in the Tuela basin (809 in Tuela and 231 in Baceiro). Crayfish were present in 16 of the 43 sites surveyed. In the Rabaçal River crayfish were present in eight sites, in Mente in one, in Tuela in five and in Baceiro in two. A clear dominance of $P$. leniusculus was found $(99.2 \%$ of the total specimens), being $P$. clarkii only present in the most downstream sites in Rabaçal and Mente Rivers and always with a very low abundance (comprising $0.8 \%$ of all specimens captured).

Average $( \pm S D)$ crayfish abundance varied between 0 in several sites and $26.3( \pm 10.1)$ ind. CPUE/24 h in R20 in the Rabaçal basin (Rabaçal and Mente Rivers) and significant differences between sites were found $\left(F_{22,186}=36.18 ; p<0.001\right.$ ) (Fig. 3a and Table S1). Average $( \pm S D)$ crayfish abundance varied between 0 in several sites and $33.2( \pm 16.4)$ ind. CPUE/24 h in site T5 in the Tuela basin (Tuela and Baceiro Rivers) and significant differences between sites were also found $\left(\mathrm{F}_{19}, 157=28.44 ; \mathrm{p}<0.001\right)$ (Fig. $3 \mathrm{~b}$ and Table S1).

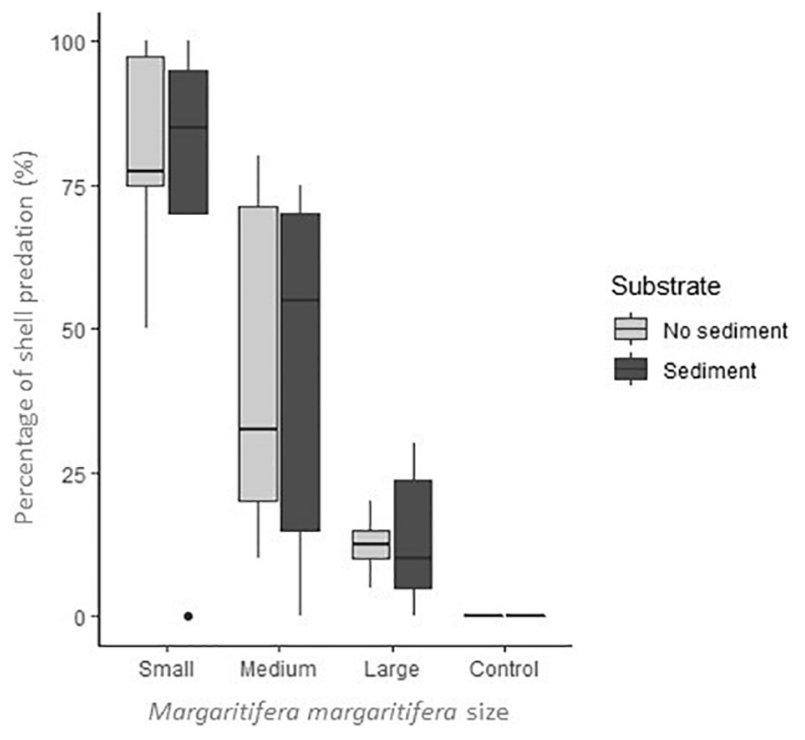

Fig. 2. Percentage of Margaritifera margartifera shell perimeter with marks of predation in different size categories by the signal crayfish Pacifastacus leniusculus. For simplicity, and because results were the same, we just present one control box plot in the treatments with and without sediment. Boxplots show median values (central line), the range from the 25th to 75th percentile (box), the largest and lowest value within 1.5 times interquartile range below and above the 25 th and 75 th percentile (whiskers) and extreme values (dots).
The length of all crayfish captured varied between 35 and $135 \mathrm{~mm}$, with an average $( \pm S D)$ of $90.0( \pm 12.5) \mathrm{mm}$. In the Rabaçal basin the average $( \pm$ SD) length of crayfish varied between $75 \mathrm{~mm}$ in $\mathrm{R} 4$ and 93.4 $( \pm 11.8) \mathrm{mm}$ in R20 and significant differences were found between sites $\left(\mathrm{F}_{8,557}=5.45 ; p<0.001\right)$ (Fig. $\left.4 \mathrm{a}\right)$. In the Tuela basin the average $( \pm \mathrm{SD})$ length of crayfish varied between $87.8( \pm 13.5) \mathrm{mm}$ in $\mathrm{T} 3$ and $112.5( \pm 3.5) \mathrm{mm}$ in T1 and significant differences were also found between sites $\left(\mathrm{F}_{6,1033}=6.465 ; \mathrm{p}<0.001\right)$ (Fig. 4b).

In the Rabaçal basin the number of females (63.6\% of individuals) were higher than males (36.4\%) and this difference was significantly different from the expected ratio of $1: 1\left(\chi^{2}=41.9 ; \mathrm{p}<0.001\right)$. In the Tuela basin the number of females (61.3\% of individuals) were also higher than males (38.7\%) and this difference was also significantly different than the expected ratio of $1: 1\left(\chi^{2}=52.6 ; p<0.001\right)$ (Fig. 5a). In the Rabaçal basin females were significantly larger than males $(\mathrm{p}<$ 0.001 ); however, in the Tuela basin no differences in total length were found between males and females ( $p=0.360$ ) (Fig. 5b).

In total we found 3160 pearl mussels in the 43 sites surveyed, being 2154 found in the Rabaçal basin (2079 in Rabaçal and 75 in Mente) and 1006 in the Tuela basin (all of them in the Tuela River since no pearl mussels were found in the Baceiro River) (Table S1). The percentage of pearl mussels with marks of predation varied between $0 \%$ in several sites and $100 \%$ in site T8. In the Rabaçal basin $4.0 \%$ of pearl mussels were found with marks of predation, being all of them found in the Rabaçal River (Table S1). However, when crayfish and pearl mussels were found in sympatry the percentage rises to $14.1 \%$. In the Tuela basin $4.5 \%$ of pearl mussels were found with marks of predation, being all of them in the Tuela River. However, when crayfish and mussels were found in sympatry this percentage rises to $70.3 \%$.

A significant correlation $\left(\mathrm{R}^{2}=0.88 ; \mathrm{F}=269.70 ; \mathrm{p}<0.001\right)$ was found between the abundance of crayfish and the percentage of pearl mussels with marks of predation in the field (Fig. 6).

\section{Discussion}

The introduction of invasive predators as a possible threat to the conservation of freshwater mussels has been rarely studied (but see Jokela and Mutikainen, 1995; Machida and Akiyama, 2013; Meira et al., 2019; Zahner-Meike and Hanson, 2001). In this study, we clearly show, using a laboratorial experiment and validation in natural conditions, that the pearl mussel M. margaritifera can be predated by the signal crayfish $P$. leniusculus. This biotic interaction may threaten the survival of $M$. margaritifera since juveniles are especially vulnerable. This situation should be carefully evaluated and management actions should be implemented given the rarity of pearl mussels (and other unionids) and the widespread distribution of invasive crayfish species in Europe.

\subsection{Signal crayfish predation on pearl mussels}

In our laboratorial experiment, we clearly showed that smaller specimens were more vulnerable to predation by the signal crayfish, presenting higher mortality and percentage of shell with marks of predation. This is possibly related to the thinner and easier to manipulate shells of the smaller pearl mussel individuals. Signal crayfishes will probably spend much less energy to open these smaller and thin shells and in this way gain more profit consuming the soft tissues. Similar results were obtained by Machida and Akiyama (2013) for Japanese pearl mussels. These authors found that only the smaller individuals suffer mortality, even though all size classes were injured by the signal crayfish. In the same vein, and using different European species (Anodonta anatina, Potomida littoralis and Unio delphinus), Meira et al. (2019) also showed that $P$. clarkii and $P$. leniusculus prefer freshwater mussel species with more thin and fragile shells (i. e., A. anatina).

Contrary to our expectations the presence of sediment in the mesocosms did not affect the predation efficiency of signal crayfish. 

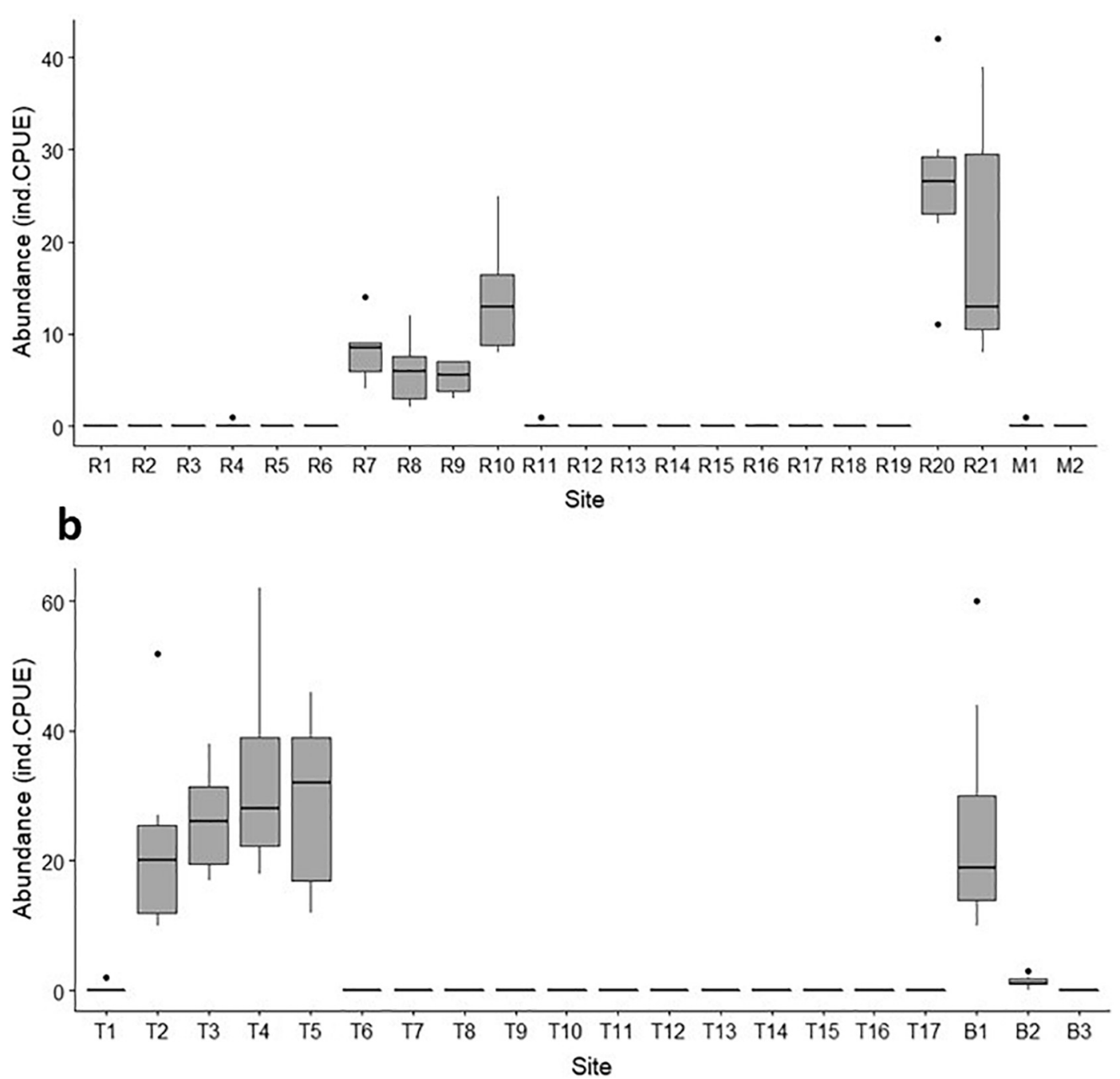

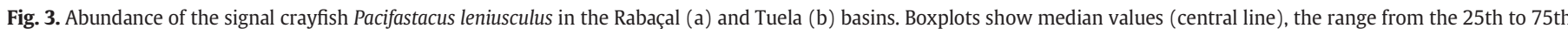
percentile (box), the largest and lowest value within 1.5 times interquartile range below and above the 25th and 75th percentile (whiskers) and extreme values (dots).

We expected that the presence of sediment turns the predation less efficient because pearl mussels would be able to burrow to avoid predation. Although several smaller pearl mussels were totally burrowed in the sediment in the beginning of the experiment, the signal crayfish easily found these specimens. This situation was possibly facilitated by the relative small size of the mesocosms used. In addition, the low (or almost absent) mobility of pearl mussels possibly enhances the probabilities of signal crayfish to find them. In an earlier study, zu Ermgassen and Aldridge (2011) described in detail how the signal crayfish forages to eat zebra mussels (Dreissena polymorpha). In summary, crayfish use the chelipeds to excavate sediment, following which the second and third pairs of pereopods are used to forage the benthos until a prey is found. We observed a similar behaviour in our experiment and the same was confirmed by Machida and Akiyama (2013). Subsequently, if the signal crayfish finds a pearl mussel, the prey is picked up by the pereopods and brought to the mouth where it is held by the maxillipeds. The mussels are chipped at the shell margins by the crayfish mandibles until the soft tissues are reached. This behaviour is responsible for the characteristic marks left by crayfish in mussel shells (see Machida and Akiyama, 2013 and Meira et al., 2019). Although not mentioned by earlier studies, and recognising the importance of the use of the chelipeds to forage, we cannot exclude the ability of the signal crayfish to detect chemical cues in the water facilitating the finding of the prey (reviewed in Ferrari et al., 2010); this situation deserves further attention in future studies.

Given the scattered distribution of the signal crayfish in both Rabaçal and Tuela basins, several sites are subjected to predation and others completely free of crayfish and still not suffering their impact. Sites with crayfish showed clear differences in abundance and size structure, which is possibly related with different abiotic conditions among sites (Anastácio et al., 2015) and/or with the distinct history of invasion in both rivers. In addition, and although not studied here, several species may predate crayfish in the study area, namely the native Eurasian otter Lutra lutra and more recently the non-native American mink Neovison vison. Therefore, the observed spatial differences in abundance and size structure of the signal crayfish can also be related to the presence/absence of these mammals.

Regarding the sex ratio, females dominated both populations in the Rabaçal and Tuela basins and the different sex ratio from the expected 1:1 may be related to the recent and still non-complete invasion. Similar results have been described in some studies also showing a sex ratio different from 1:1 (e.g., Capurro et al., 2007; Wutz and Geist, 2013).

A clear relationship between the abundance of crayfish and percentage of pearl mussels presenting marks of predation was found. Although 

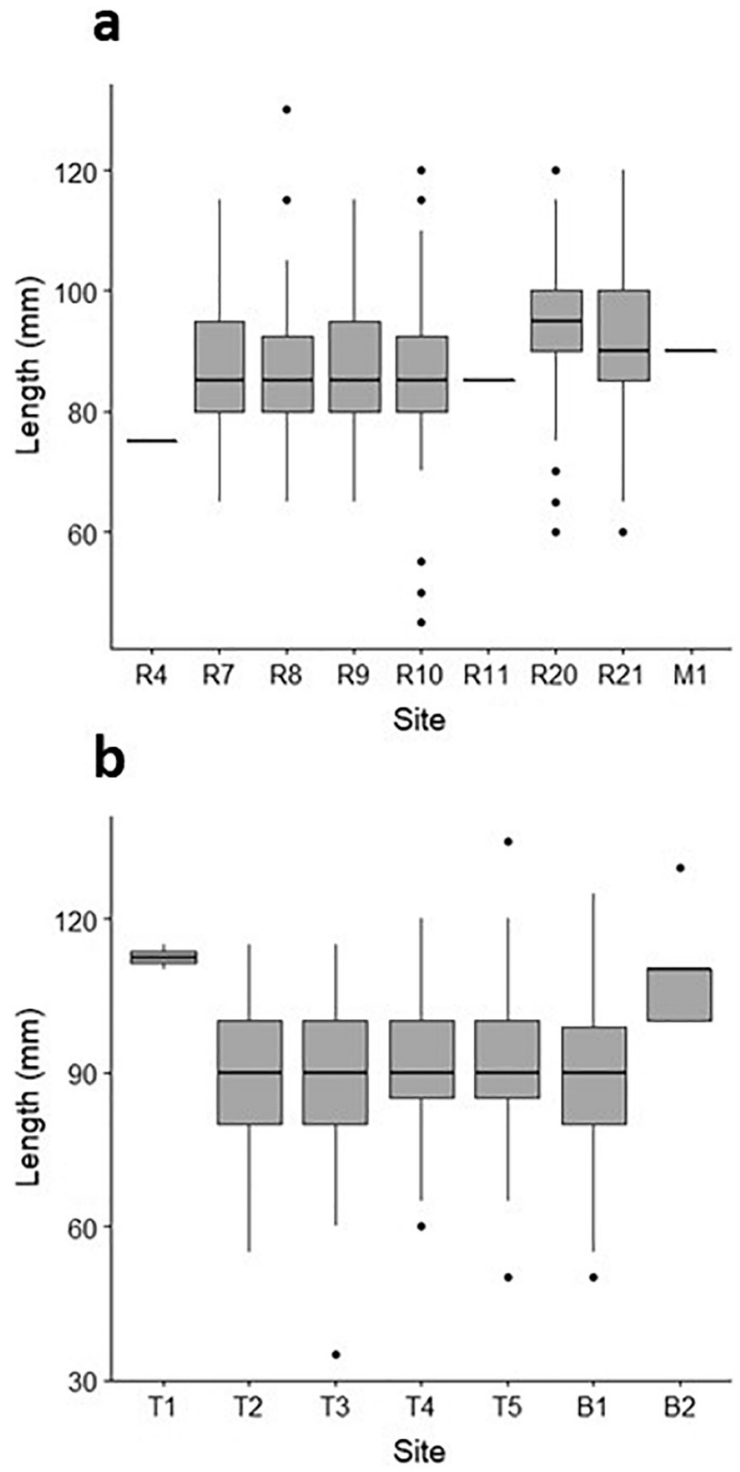

Fig. 4. Length of the signal crayfish Pacifastacus leniusculus in the Rabaçal (a) and Tuela (b) basins. Boxplots show median values (central line), the range from the 25th to 75 th percentile (box), the largest and lowest value within 1.5 times interquartile range below and above the 25 th and 75 th percentile (whiskers) and extreme values (dots).

this data cannot be seen as true predation (and consequent mortality of prey) can, on the other hand, be used as a proxy of threat since it is reasonable to think that more marks of predation will be observed when crayfish reach higher abundances. Anyway, some variation in the percentage of predation marks in sites with similar crayfish abundance was observed and this may be explained by the presence of refuges (in areas with higher water current) or even the presence of great quantities of leaf litter in some sites may difficult the foraging behaviour of the crayfish. Another important aspect may be the availability of other food resources (e.g., other invertebrates) more easily predated by the signal crayfish than the pearl mussels. In these sites, the crayfish may have a high abundance but probably rely less on pearl mussels due to the energetic demands to open bivalve shells in comparison to other more profitable and easily to handle prey species.

\subsection{Conservation implications}

According to Cox and Lima (2006) naiveté is the result of lack of contact between predator archetypes and prey species over evolutionary

a

b
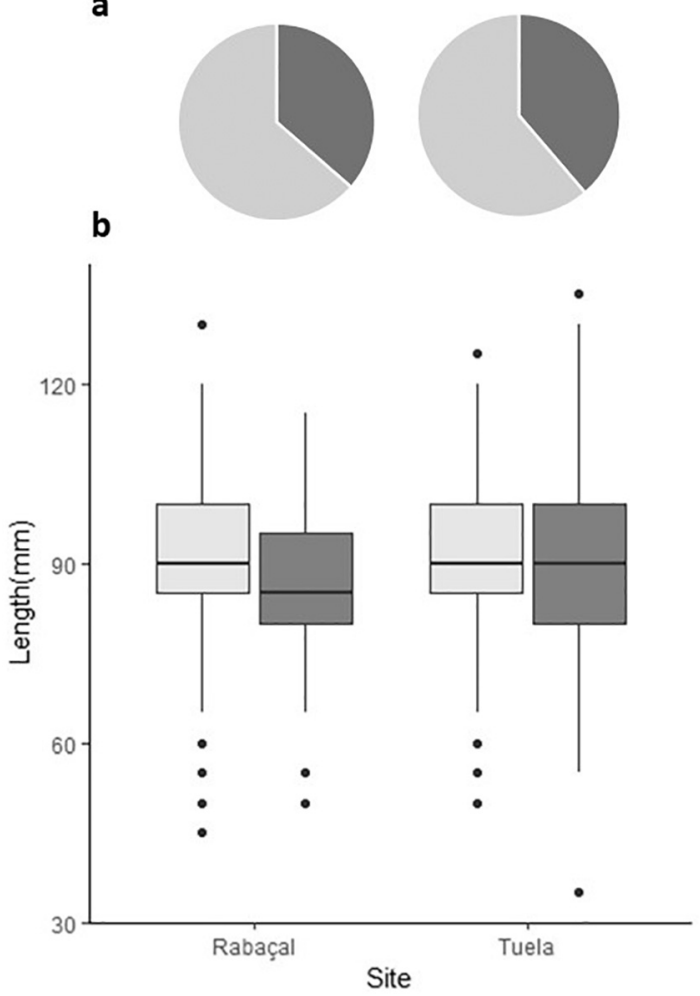

Fig. 5. Percentage of males and females of the signal crayfish Pacifastacus leniusculus in the Rabaçal and Tuela basins (a). Length of males (M) and females (F) of the signal crayfish Pacifastacus leniusculus in the Rabaçal and Tuela basins (b). Boxplots show median values (central line), the range from the 25 th to 75 th percentile (box), the largest and lowest value within 1.5 times interquartile range below and above the 25 th and 75 th percentile (whiskers) and extreme values (dots).

time. Pearl mussels in the study area appear to be naïve to signal crayfish due to the lack of ineffective defences against this kind of predator archetype. Therefore, and in the current conditions, pearl mussels (mainly juveniles) appear to lack the appropriate defences against crayfish or fail to recognise the crayfish as a potential enemy and in this way change their morphology (e.g., growing thicker shells), and behaviour (e.g., burrowing deeper in the sediments and/or finding appropriate refuges). Pearl mussels in Portugal were probably never exposed to predation by crayfish or a similar (such as freshwater crabs) archetype predator. Indeed, the status of Austropotamobius italicus as a native or a non-native species in Iberia is highly controversial, with some studies recognising that this crayfish is an introduction from the 16th century (Clavero et al., 2016). Nevertheless, and although the status of

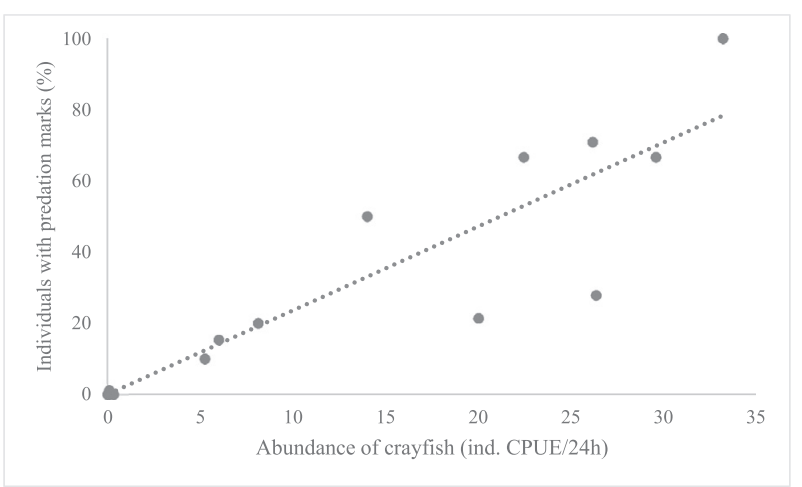

Fig. 6. Relationship between the abundance of signal crayfish Pacifastacus leniusculus and percentage of Margaritifera margaritifera individuals with predation marks. 
A. italicus in Iberia as native or non-native is still debatable, there are no past records of this crayfish species in the Tua basin. Therefore, M. margaritifera populations in the Rabaçal and Tuela basins were possibly never exposed to such a type of predator. In the same way, the signal crayfish in North America has a sympatric distribution with several freshwater mussel species (Larson et al., 2012). Consequently, the signal crayfish is probably highly adapted to predate these organisms. The naiveté of pearl mussels of the study area and the high predatory capacity of crayfish on freshwater mussels (Machida and Akiyama, 2013; Meira et al., 2019; this study), together with the usual higher vulnerability of freshwater ecosystems (when compared to terrestrial or marine ecosystems) to introduced predators (Cox and Lima, 2006), may determine the high negative impacts of signal crayfish on pearl mussels. However, this situation may change because some studies show how bivalves rapidly recognise introduced predators and alter their morphology investing in more thick shells in a few generations after co-existence (Freeman and Byers, 2006). Only further quantitative studies may evaluate which species become more efficient in this evolutionary arms race.

Besides the direct impact on pearl mussels and respective increase in mortality, other indirect effects are possible at the population, community and ecosystem levels. In fact, it may happen that pearl mussels that survive the signal crayfish attack have to spend energy in shell regeneration with possible high energetic cost that may affect growth and reproduction. In addition, and although speculative, if pearl mussels already recognise the crayfish as a predator, they may possibly maintain the valves closed for more time and doing so will filtrate and produce faeces and pseudofaeces in much less quantities than in normal conditions (see Wilson et al., 2012). In oligotrophic ecosystems, such as the ones colonised by pearl mussels, this situation may have cascading effects in several trophic levels given the high density and biomass attained by these animals in several surveyed sites. In fact, because this species may be responsible for important trophic and non-trophic interactions such as nutrient cycling, providing habitat to other species, purification of the water, among others, their decline or decreases in filtration and/or excretion rates may affect not only the benthic community but also adjacent terrestrial habitats (Vaughn and Hoellein, 2018).

In conclusion, and given the critically endangered status of pearl mussels in Europe and the widespread distribution of signal crayfish (and other crayfish species) in this continent, the possible negative effects of predation should not be neglected. Future management actions devoted to the conservation of pearl mussels should seriously consider the necessity of control or even eradicate this crayfish species, at least in priority habitats where dense pearl mussel beds are present. In the particular case of our study, we were able to map the areas with higher predation pressure that may inform the future application of mitigation measures (i.e., delineate areas where the control or even the eradication of crayfish can be performed) to conserve the most viable southernmost European M. margaritifera populations. In fact, the best river stretches for pearl mussel conservation in the Tuela basin are still not colonised by crayfish and so a careful management program should be implemented to contain the signal crayfish below the small dam that still constitutes a physical barrier to dispersion, complemented by prevention measures (including information to local population) and early detection programs. In the same vein, the best river stretches for pearl mussel conservation in the Rabaçal basin are also located upstream of the dams. However, in this river and in the upper catchment area near the border with Spain, the signal crayfish is already present in high abundance. In this particular, and given the still restricted spatial distribution of the signal crayfish in the Rabaçal River, will be important that control or even eradication programs are initiated as soon as possible. Since both threatened pearl mussel populations are mostly located in the protected area of Montesinho Natural Park, adequate management measures must be implemented by governmental services and other partners (e.g. academia, fishermen associations, NGO's) to promote the conservation of natural values in both river basins.
Supplementary data to this article can be found online at https://doi. org/10.1016/j.scitotenv.2019.02.094.

\section{Acknowledgments}

This work was supported by: i) POSEUR (15-2018-03) and ICNF funds under project CP01-MARG-QUERCUS/2018 and ii) European Investment Funds by FEDER/COMPETE/POCI - Operational Competitiveness and Internationalization Program, under Project POCI-01-0145FEDER-006958 and National Funds by FCT - Portuguese Foundation for Science and Technology, under the project UID/AGR/04033/2013. FCT also support MLL with a doctoral grant (SFRH/BD/115728/2016). We thank the four anonymous reviewers for the suggestions made, which significantly improved the clarity of the manuscript.

\section{References}

Anastácio, P.M., Banha, F., Capinha, C., Bernardo, J.M., Teixiera, A., Bruxelas, S., 2015. Indicators of movement and space use for two co-occurring invasivecrayfish species. Ecol. Indic. 53, 171-181.

Anastácio, P.M., Ribeiro, F., Capinha, C., Banha, F., Gama, M., Filipe, A.F., Rebelo, R., Sousa R., 2019. Non-native freshwater fauna in Portugal: a review. Sci. Total Environ. 650, 1923-1934.

Bernardo, J.M., Costa, A.M., Bruxelas, S., Teixeira, A., 2011. Dispersal and coexistence of two non-native crayfish species (Pacifastacus leniusculus and Procambarus clarkii) in NE Portugal over a 10-year period. Knowl. Manag. Aquat. Ecosyst. (401), 28.

Blackburn, T.M., Cassey, P., Duncan, R.P., Evans, K.L., Gaston, K.J., 2004. Avian extinction and mammalian introductions on oceanic islands. Science 305, 1955-1958.

Capurro, M., Galli, L., Mori, M., Salvidio, S., Arillo, A., 2007. The signal crayfish, Pacifastacus leniusculus (Dana 1852) [Crustacea: Decapoda: Astacidae], in the Brugneto Lake (Liguria, NW Italy). The beginning of the invasion of the River Po watershed? Aquat. Invasions 2, 17-24.

Carvalho, F., Pascoal, C., Cássio, F., Sousa, R., 2016. Direct and indirect effects of an invasive omnivore crayfish on leaf litter decomposition. Sci. Total Environ. 541, 714-720.

Clavero, M., Nores, C., Kubersky-Piredda, S., Centeno-Cuadros, A., 2016. Interdisciplinarity to reconstruct historical introductions: solving the status of cryptogenic crayfish. Biol. Rev. 91, 1036-1049.

Cox, J.G., Lima, S.L., 2006. Naiveté and an aquatic-terrestrial dichotomy in the effects of introduced predators. Tends Ecol. Evol. 21, 674-680.

Croll, D.A., Maron, J., Estes, J., Danner, E.M., Byrd, G.V., 2005. Introduced predators transform subarctic islands from grassland to tundra. Science 307, 1959-1961.

Doherty, T.S., Glen, A.S., Nimmo, D.G., Ritchie, E.G., Dickman, C.R., 2016. Invasive predators and global biodiversity loss. Proc. Natl. Acad. Sci. U. S. A. 113, 11261-11265.

Dorcas, M.E., Willson, J.D., Reed, R.N., Snow, R.W., Rochford, M.R., Miller, M.A., Meshaka Jr., W.E., Andreadis, P.T., Mazzotti, F.J., Romagosa, C.M., Hart, K.M., 2012. Severe mammal declines coincide with proliferation of invasive Burmese pythons in Everglades National Park. Proc. Natl. Acad. Sci. U. S. A. 109, 2418-2422.

Ferrari, M.C.O., Wisenden, B.D., Chivers, D.P., 2010. Chemical ecology of predator-prey interactions in aquatic ecosystems: a review and prospectus. Can. J. Zool. 88, 698-724.

Ferreira-Rodríguez, N., Sousa, R., Pardo, I., 2018. Negative effects of Corbicula fluminea over native freshwater mussels. Hydrobiologia 810, 85-95.

Freeman, A., Byers, J.E., 2006. Divergent induced responses to an invasive predator in marine mussel populations. Science $313,831-833$

Fukami, T., Wardle, D.A., Bellingham, P.J., Mulder, C.P.H., Towns, D.R., Yeates, G.W., Bonner K.I., Durrett, M.S., Grant-Hoffman, M.N., Williamson, W.M., 2006. Above- and belowground impacts of introduced predators in seabird-dominated island ecosystems. Ecol. Lett. 9, 1299-1307.

Geist, J., 2010. Strategies for the conservation of endangered freshwater pearl mussels (Margaritifera margaritifera L.): a synthesis of conservation genetics and ecology. Hydrobiologia 644, 69-88.

Gherardi, F., Aquiloni, L., Diéguez-Uribeondo, J., Tricarico, E., 2011. Managing invasive crayfish: is there a hope? Aquat. Sci. 73, 185-200.

Jokela, J., Mutikainen, P., 1995. Effect of size-dependent muskrat (Ondatra zibethica) predation on the spatial distribution of a freshwater clam, Anodonta piscinalis Nilsson (Unionidae, Bivalvia). Can. J. Zool. 73, 1085-1094.

Kurle, C.M., Croll, D.A., Tershy, B.R., 2008. Introduced rats indirectly change marine rocky intertidal communities from algae- to invertebrate-dominated. Proc. Natl. Acad. Sci. U. S. A. $105,3800-3804$.

Larson, E.R., Abbott, C.L., Usio, N., Azuma, N., Wood, K.A., Herborg, L.M., Olden, J.D., 2012 The signal crayfish is not a single species: cryptic diversity and invasions in the Pacific Northwest range of Pacifastacus leniusculus. Freshw. Biol. 57, 1823-1838.

Lopes-Lima, M., Sousa, R., Geist, J., Aldridge, D.C., Araujo, R., Bergengren, J., Bespalaya, Y. Bódis, E., Burlakova, L., Van Damme, D., Douda, K., Froufe, E., Georgiev, D., Gumpinger C., Karatayev, A., Kebapci, U., Killeen, I., Lajtner, J., Larsen, B., Lauceri, R., Legakis, A., Lois, S., Lundberg, S., Moorkens, E., Motte, G., Nagel, K.-O., Ondina, P., Outeiro, A. Paunovic, M., Prié, V., von Proschwitz, T., Riccardi, N., Rudzīte, M., Rudzītis, M. Scheder, C., Seddon, M., Sereflișan, H., Simic, V., Sokolova, S., Stoeckl, K., Taskinen, J., Teixeira, A., Thielen, F., Trichkova, T., Varandas, S., Vicentini, H., Zajac, K., Zajac, T., Zogaris, S., 2017. Conservation status of freshwater mussels in Europe: state of the art and future challenges. Biol. Rev. 92, 572-607. 
Machida, Y., Akiyama, Y.B., 2013. Impacts of invasive crayfish (Pacifastacus leniusculus) on endangered freshwater pearl mussels (Margaritifera laevis and M. togakushiensis) in Japan. Hydrobiologia 720, 145-151.

Maron, J.L., Estes, J.A., Croll, D.A., Danner, E.M., Elemndorf, S.C., Buckelew, S.L., 2006. An introduced predator alters Aleutian Island plant communities by thwarting nutrient subsidies. Ecol. Monogr. 76, 3-24

Meira, A., Lopes-Lima, M., Varandas, S., Teixeira, A., Arenas, F., Sousa, R., 2019. Invasive crayfishes as a threat to freshwater bivalves: interspecific differences and conservation implications. Sci. Total Environ. 649, 938-948.

Oliveira, J.M., Segurado, P., Santos, J.M., Teixeira, A., Ferreira, M.T., Cortes, R.V., 2012 Modelling stream-fish functional traits in reference conditions: regional and local environmental correlates. PLoS One (9), e45787.

Pringle, R.M., 2011. Nile perch. In: Simberloff, D., Rejmánek, M. (Eds.), Encyclopedia of Biological Invasions. University of California Press, Berkeley and Los Angeles, pp. 484-488.

Rogers, H.S., Buhle, E.R., HilleRisLambers, J., Fricke, E.C., Miller, R.H., Tewksbury, J.J., 2017. Effects of an invasive predator cascade to plants via mutualism disruption. Nat. Commun. 8, 14557.

Santos, R.M.B., Sanches Fernandes, L.F., Varandas, S.G.P., Pereira, M.G., Sousa, R., Teixeira, A., Lopes-Lima, M., Cortes, R.M.V., Pacheco, F.A.L., 2015. Impacts of climate change and land-use scenarios on Margaritifera margaritifera, an environmental indicator and endangered species. Sci. Total Environ. 511, 477-488.

Sousa, R., Varandas, S., Cortes, R., Teixeira, A., Lopes-Lima, M., Machado, J., Guilhermino, L. 2012. Massive die-offs of freshwater bivalves as resource pulses. Ann. Limnol.-Int. J. Limnol. 48, 105-112.

Sousa, R., Amorim, A., Sobral, C., Froufe, E., Varandas, S., Teixeira, A., Lopes-Lima, M. 2013a. Ecological status of a Margaritifera margaritifera (Linnaeus 1758) population at the southern edge of its distribution (River Paiva, Portugal). Environ. Manag. 52, 1230-1238.

Sousa, R., Freitas, F., Nogueira, A.J.A., Mota, M., Antunes, C., 2013b. Invasive dynamics of the crayfish Procambarus clarkii (Girard, 1852) at the international section of the River Minho (NW of the Iberian Peninsula). Aquat. Conserv. 23, 656-666.
Sousa, R., Novais, A., Costa, R., Strayer, D., 2014. Invasive bivalves in fresh waters: impacts from individuals to ecosystems and possible control strategies. Hydrobiologia 735, 233-251.

Sousa, R., Amorim, A., Froufe, E., Varandas, S., Teixeira, A., Lopes-Lima, M., 2015. Conservation status of the freshwater pearl mussel Margaritifera margaritifera in Portugal. Limnologica 50, 4-10.

Sousa, R., Ferreira, A., Carvalho, F., Lopes-Lima, M., Varandas, S., Teixeira, A., 2018. Die-offs of the endangered pearl mussel Margaritifera margaritifera during an extreme drought. Aquat. Conserv. 28, 1244-1248.

Varandas, S., Lopes-Lima, M., Teixeira, A., Hinzmann, M., Reis, J., Cortes, R., Machado, J., Sousa, R., 2013. Ecology of Southern European pearl mussels (Margaritiferamargaritifera): first record of two new populations on the rivers Terva and Bec, a(Portugal). Aquat. Conserv. 23, 374-389.

Vaughn, C.C., Hoellein, T.J., 2018. Bivalve impacts in freshwater and marine ecosystems. Annu. Rev. Ecol. Evol. S. 49, 183-208.

Wilson, C.D., Arnott, G., Elwood, R.W., 2012. Freshwater pearl mussels show plasticity of responses to different predation risks but also show consistent individual differences in responsiveness. Behav. Process. 89, 299-303.

Wutz, S., Geist, J., 2013. Sex- and size-specific migration patterns and habitat preferences of invasive signal crayfish (Pacifastacus leniusculus Dana). Limnologica 43, 59-66.

Zahner-Meike, E., Hanson, J.M., 2001. Effect of muskrat predation on naiads. In: Bauer, G., Wächtler, K. (Eds.), Ecology and Evolution of the Freshwater Mussels Unionoida. Springer, Berlin, pp. 163-184.

Zar, J.H., 2009. Biostatistical Analysis. 5th ed. Prentice-Hall, Englewood Cliffs.

zu Ermgassen, P.S.F., Aldridge, D.C., 2011. Predation by the invasive American signal crayfish, Pacifastacus leniusculus Dana, on the invasive zebra mussel, Dreissena polymorpha Pallas: the potential for control and facilitation. Hydrobiologia 658, 303-315. 